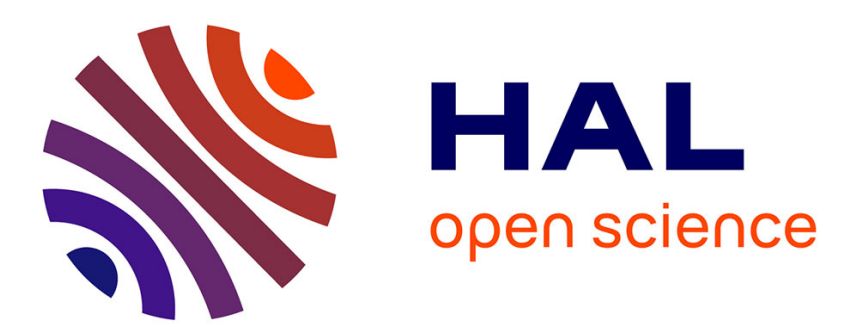

\title{
Mapping Mobile Borders: Critical Cartographies of Borders Based on Migration Experiences
}

\author{
Sarah Mekdjian
}

\section{To cite this version:}

Sarah Mekdjian. Mapping Mobile Borders: Critical Cartographies of Borders Based on Migration Experiences. Anne-Laure Amilhat Szary; Frédéric Giraut. Borderities and the Politics of Contemporary Mobile Borders, Palgrave MacMillan, 2015, 978-1-137-46885-7. halshs-01242523

\section{HAL Id: halshs-01242523 \\ https://shs.hal.science/halshs-01242523}

Submitted on 16 Dec 2015

HAL is a multi-disciplinary open access archive for the deposit and dissemination of scientific research documents, whether they are published or not. The documents may come from teaching and research institutions in France or abroad, or from public or private research centers.
L'archive ouverte pluridisciplinaire HAL, est destinée au dépôt et à la diffusion de documents scientifiques de niveau recherche, publiés ou non, émanant des établissements d'enseignement et de recherche français ou étrangers, des laboratoires publics ou privés. 


\section{CHAPTER PUBLISHED IN:}

Borderities and the Politics of Contemporary Mobile Borders

Anne Laure Amilhat Szary, Frédéric Giraut

Palgrave McMillan

2015

pp. 204-224

A preview is available here :

http://www.palgraveconnect.com/pc/doifinder/view/10.1057/9781137468857.0019

\section{MAPPING MOBILE BORDERS. Critical cartographies of borders based on migration experiences.}

Sarah Mekdjian

\section{[A] INTRODUCTION}

Borders cannot be reduced to a linear and territorial conception. The field of border studies has largely been revitalized by studies on borderlands and border zones (Anzaldua, 2012; Rösler, Wendl, 1999; Brunet-Jailly, 2007), which have added to the complexity of the stato-national conception of borders. Furthermore, over and above the study of borders themselves, the processes of bordering / debordering / rebordering have been analysed (Van Houtum, Kramsch, Ziefhofer, 2004; Popescu, 2011). Contemporary border functions have been redefined with the help of migration and mobility studies, so that their role as a barrier or border interface is diffused in space and time, according to state policies, notably migration policies. Works on the externalization of borders (Ferrer-Gallardo, 2008; Audebert, Robin, 2009; Casas, Cobarrubias, Pickles, 2011), have also contributed to a critique of the normative paradigm of the fixed borderline. As Perkins and Rumford explain, 'bordering-as-process, coupled with a general interest in a range of mobilities, has led to the recognition that borders can be mobile to the same extent as those who seek to cross them' (Perkins, Rumford, 2013, p. 268). Within the framework of the study of border politics, the notion of 'borderities', developed in this book, allows us to study the multiplication, transformation and spatiotemporal mobility of contemporary border functions.

In this chapter we will focus on the question of the mapping of these complex and evolving borderities. Border mapping is evidence of these political transformations; we may note the move from modern mapping that legitimized the idealised vision of fixed borders to the emergence of mobile geo-surveillance mapping techniques. If the role of maps was central in the production and diffusion of the territorial model of the nation state (Harley, 2001), today mapping is part of the progressive dematerialization, virtualization and mobility of borders, serving new regimes of state governmentality (Walsh, 2013).

However mapping cannot be viewed as merely an instrument of governmentality; it is also used by researchers, activists and artists working on a critique of contemporary border, migration policies and the apparatus of surveillance. Counter-cartography projects (Counter Cartographies Collective, Dalton, Mason-Deese, 2012) have largely been involved in producing alternative visual narratives of borders ${ }^{1}$.

We will be looking at the conditions for the emergence of critical maps and mapping performances which go beyond the state-centric perspective of conventional border maps ${ }^{2}$, and which allow us to analyze critically the cartographic practices of geo-surveillance, particularly in

1 See for example the critical cartography of the Strait of Gibraltar produced in 2004 by Spanish collective Hackitectura (http://hackitectura.net/blog/en/2004/cartografia-del-estrecho/, date accessed 8 June 2014).

2 Many state-centred analyses have been based on a study of the evolution of state border policies for controlling and filtering international migrations: 'although these studies highlight the experience of [migrants], they focus on the perspective of state agents rather than the crosser' (Chavez, $2011: 1323$ ). 
the context of migration. Our purpose is to envision a critical border cartography based on the study and visualization of borders from the perspective of those who try to cross them and who are excluded from the right of migration. By choosing to focus in particular on individual experiences of migrants, the aim is to contribute to the decentralization of state metanarratives on border politics, as suggested by Perkins and Rumford (2013). These authors encourage a stronger social and critical movement in border studies 'where considerations of state would not frame all visions of bordering [...]. Such a border studies would make different assumptions about the role of people in bordering activity' (Perkins, Rumford, 2013, p.268). Perkins and Rumford talk about '"vernacularised" border studies which emphasise the role of ordinary people in bordering activity and the potential for connectivity that borders often display, coupled with a recognition that borders are not always a possession of the nation state' (Perkins, Rumford, 2013, p.267). Within this framework, one may ask how a critical cartography of borderities can enable a 'resubjectification' (Gibson-Graham, 2002) of border studies. In other words, how can cartography be used as a critical tool for the alternative political arrangement of contemporary borderities?

In the first section of this chapter, we will show the critical potential of studying mobile, evolving borders through migrant experiences. Then we will analyse different cartographic forms and practices in visualising mobile borders, by highlighting critical mapping practices. Finally, we will describe an attempt at a participatory and experimental mapping of mobile borders carried out by researchers in geography, artists and asylum seekers in France.

\section{[A] THE MOBILITY OF CONTEMPORARY BORDERITIES}

S., an Algerian refugee in France, told me about her journey from Algeria to France. Through her story, S. retraced her long, winding journey, with barriers constantly placed between her and her need to build a new life. After a very long wait, she gained refugee status in France. Algeria, Turkey, police custody, a detention camp, Algeria, Syria, Turkey, Greece, police custody, another detention camp, Italy, police custody, France, administrative offices, waiting, OFPRA ${ }^{3}$, waiting, $\mathrm{CNDA}^{4}$, more waiting and finally refugee status.

The border crossings in S.'s account were not simply those from one country to another, although it was while crossing such geopolitical frontiers that she was arrested or that other significant events in her story took place. Her account of her administrative journey in France en route to the granting of refugee status also involved constant borders, barriers both tangible and intangible, which excluded her from most of the basic rights of an individual. S. also recounted the extent to which the spatiotemporal scope of her journey was relative to the people and institutions that she encountered along the way. Her route had not been thought out and planned, but rather developed en route, according to events, luck, opportunities and misfortune. The complexity of her journey implies the need to rethink the spread of border functions over and beyond simple frontier lines.

Research on international migration in the field of social sciences is increasingly devoted to complex space-time covered during migratory journeys that are highly monitored and controlled. The mobility of techniques for the control of migrants, and the internment measures in transit and destination countries, contribute to the spread of border spaces across all the state territories involved in migration, including their sovereign maritime spaces (Audebert, Robin, 2009; Casas, Cobarrubias, Pickles, 2011).

Borders are mobile because they are not only being externalized over increasingly great areas, but also deterritorialized, as is explained by researchers reflecting on an agenda for critical border studies: 'borders are not only found at territorially identifiable sites such as ports, airports, and other traditional "border crossings". Instead, they are increasingly ephemeral and/or

3 OFPRA: Office Français de Protection des Réfugiés et Apatrides; French Office for the Protection of Refugees and Stateless People.

4 CNDA: Cour Nationale du Droit d'Asile; French Court reviewing appeals on refugee status and the asylum right. 
impalpable: electronic, non-visible, and located in zones that defy a straightforwardly territorial logic' (Parker, Vaughan-Williams, 2009, p.583). While this is not to say that 'borders are everywhere' (Paasi, 2009), it is very important to evaluate the processes of deterritorialization and reterritorialization, with a reterritorialization of border functions that is paradoxically diffuse and mobile. From the point of view of illegal migrants, borders correspond to all the space and time covered during their journey. Physical difficulties, the threat of arrest and constraints imposed on the right to residence, asylum and work, are all barriers which they come across all along the way, connected to strategies for crossing, avoiding, confronting and opposing these. Considered from the point of view of individual migration experiences, borders can be seen as 'evolving mobile borders $^{\prime 5}$, in the sense of mobile and qualitative space-time relative to the politics of mobilites and the movements of migrants.

If cartography has largely contributed to the diffusion of the norm of fixed, territorial borders, it is essential to work on gathering data on the mobility of contemporary borderities in order to rethink border mapping. This effort is part of an epistemological project in which the cartographic representation of borders, relative to migration experiences, may serve as a critical tool in border politics.

How are border maps to be revisited from the standpoint of maps of itineraries which 'provide a representation of the territory in which that territory is not considered independently of the practices carried out within it $[\ldots]$ but rather is defined in its very structure by the practical actions of those who move therein' (Besse, 2010, p.7)? At stake is a geographic and cartographic redefinition of border crossings; rather than crossing from one side of a border to the other, crossing a border that is built up 'on the way' corresponds to a movement that includes differentiated rhythms and temporalities, stages, bifurcations, choices and constraints, relative to political, individual and collective situations. It also involves the redefinition of the links between migrants and border politics: rather than being considered merely as targets - objects - of border politics, migrants are also treated as subjects, whose journeys have a part to play in the evolution of contemporary borderities.

In the following section we will try to show how a map can be at one and the same time a disciplinary tool used to objectify migration movements and border naturalization, and a critical tool for current borderities, as representation, practice and performance.

\section{[A] CAN CARTOGRAPHY HELP TO CRITICALLY ENGAGE WITH CONTEMPORARY BORDERITIES ?}

Border maps have been critically examined 'as products imbued with power' (Del Casino, Hanna, 2006: 34). As political and geographical constituents of state sovereignty, border maps are part of the 'normative discourse of the generic, idealized state as an internal space, with governance, unity, stasis, fixity' (Steinberg, 2009, p.469). Cartography has thus been part of the idealization of the fixed frontiers of modern states, conceived of in opposition to movement ${ }^{6}$. Contemporary border

\footnotetext{
5 The notion of the 'evolving border', I suggest here, relates to hodology, defined by Brinckerhoff Jackson as 'the science or study of roads' (Brinckerhoff Jackson, 1984, p. 21). Understanding space by its roads, and more especially through movement along the way, is to accept a change in one's point of view, to conceive of a qualitative space orientated towards multiple objectives. As Tiberghien explains, 'hodology is interested in routes, in roads and different communicative pathways: that also means that it takes account of those who use them, who 'use' them for the period of a journey which may be short or long' (Tiberghien, 2004, p.8). Crossing a border, especially clandestinely, means in effect following a number of routes, orientated towards an uncertain objective that is often redefined along the way.

6 This opposition between movement and the modern conception of borders must, however, be nuanced. Modern mapping of borders itself is not merely confined to fixity, as Steinberg showed when he studied the maps of oceans produced in Europe from the $17^{\text {th }}$ century onwards (Steinberg, 2009).
} 
mapping has not distanced itself from its modern function of delineating state territory, but is more and more associated with the technology of mobile surveillance. It is important here to distinguish between the state mapping of borders and the use of cartography by states: 'in addition to 'bounding' societies within delimited territorial zones, mapping technologies have recently been elevated to encompass observing, locating, and tracking mobile bodies' (Walsh, 2013, p.969). The affirmation of fixed, idealized borders is inevitably accompanied by the observation and surveillance of mobility; these two elements, far from being contradictory, are mutually reinforcing (Amoore, Marmura, Salter, 2008).

However the development of inter-disciplinary research concerning theoretical and methodological dimensions of migration and border studies has led to the production of critical cartographies of borderzones in relation with migration itineraries. At stake is a border cartography which shows the movement and adaptability of both the migrants and the apparatus of surveillance. Mobile borders change place, mechanisms and structures according to the social, geographic and political situations in which the individuals find themselves. In other words, 'different places emerge from the presence of different people' (Retaillé, Walther, Pissoat, 2012, p.8). In the following sections we intend to show several kinds of contemporary research on the critical visualization of migration and border mobility.

\section{[B] Visualizing biographical data on migrations, building mobile fieldworks for a critical cartography of borders}

Qualitative and critical maps of borders often consist of the visualization of biographical data associated with individual journeys, reconstructed from a migrant's account. For example, we can cite the cartography of the journey of $\mathrm{Khan}^{7}$, a migrant of Afghan origin, which was published in Atlas of Migration in Europe. A Critical Geography of Migration Policies (Clochard, Réseau MIGREUROP, 2012). Khan's journey from Kaboul to Calais includes a detailed account of the means of transport used, the presence or absence of people smugglers... Border crossings are key moments in Khan's journey; beyond these particular crossings, his whole journey from Kaboul to Calais is analysed like a border crossing in all its spatiotemporal scope: 'By retracing this journey in both its spatial and temporal dimension, this map aims to examine the borders of the European Union, which can only be understood by looking into the experiences of those who have had to face them.' (Clochard, Réseau MIGREUROP, 2012, p.122). The way in which the places travelled through and lived in during the journey exercise their role as a border varies along a differentiated scale of perception, depending on the individual itinerary. In S.'s account mentioned earlier, her stays in Turkish and Greek detention camps were explained in different ways. S. talked of an 'open' camp in Turkey and a 'closed' camp in Greece, when in fact neither camp allowed detainees to leave freely, either by day or by night. The fact that the camp in Turkey was more 'comfortable' and the other in Greece was 'very difficult', led S. to distinguish clearly between them and thus to describe different degrees of surveillance, constraint and imprisonment.

Another possible methodology for documenting and then mapping mobile borders is the construction of a mobile research area, that is, when the researcher travels with those crossing borders in order to understand the breadth and characteristics of contemporary control measures.

Rather than investigating the workings of a border by being on one 'side' of it or on the other, a multi-sited, mobile methodology aims to multiply the viewpoints by moving across border zones. This ethnographic methodology, which is inherited from the works of Marcus (1995), is particularly suitable for constructing the geography of borders by taking into account the viewpoint of individuals moving across them. Pliez, for example, used a multi-site methodology for analysing migration geography in the Sahara (Pliez, 2011), as did Tarrius when studying migrations across the Mediterranean (Tarrius, 2002). An analysis of borders and their associated migration dynamics

7 To see the map : http://www.armand-colin.com/upload/map_32_4_ParcoursKhan_Internet.pdf, date accessed 8 June 2014. This map was built up from qualitative data collected during an ethnographic inverview carried out with Khan by Emmanuelle Hellio in February 2012. 
involves the construction of a moving area in order to set out a geography of movement. Brachet (2012) developed a reflexive analysis of his working methods in the field, based on research carried out over some three years (2003-2009) in Niger, on (trans-) Saharan crossings. The author explains that 'mobility is in itself a "field-site", a privileged moment of observation and discussion. As a consequence, researchers themselves need to become mobile in order to study migration from the inside and to grasp the fleeting and unstable social constructions that mobility produces' (Brachet, 2012, p.543). In an article on border crossings into the USA made by illegal Mexican workers, Chavez explains that he 'crossed the border four to six times per week between 4:00 am and 8:00 am, the peak time for travel to work, to understand the experiences of this labour community. I also rode the San Diego Trolley and Mexican buses and taxis to document how people moved from their homes in Mexico to their places of work in the US and how they developed connections to other crossers' (Chavez, 2011, p.1324).

Biographical analysis and mobile methods offer interesting perpectives for a critical cartography of borders, even if these methods often maintain a clear distinction between the observer and the observed (Chataway, 2001). The next section reviews some of the values and limitations of participatory methods to collect and visualize data on mobile borders.

\section{[B] Participatory mapping of migrations and border crossings}

In the field of critical mapping, participatory cartography has developed considerably with the collaborative construction of GIS, mental mapping and other visual tools by researchers and community members. Although participation is a critical method which has greatly contributed to the redefinition of cartography and geography, it does pose ethical, theoretical and methodological issues (Elwood, 2006, 2007; Dunn, 2007). The participation of migrants, particularly illegal migrants, in a research project on borders, involves specific ethical issues. Bernardie-Tahir and Schmoll wonder about 'the voices of the researchers and the words of the migrants' in a critical and reflexive analysis of research carried out in Malta amongst illegal migrants (Bernardie-Tahir, Schmoll, 2012). Over and above the particularities of migrant studies, one is bound to question, as in Spivak's text 'Can the subaltern speak?' (Spivak, 1988), the means and ends of the participatory approach. As Fistetti explains in a commentary on Spivak, it is important to beware of 'any essentialism, any search for primary sources, any claims to capturing the "purity" of the subaltern's "voice"' (Fistetti, 2009). Participatory maps do not 'represent' the condition of the individuals who have in part produced them; they are obviously not exempt from the power relations at work amongst the participants. Furthemore, the emotional and sensitive dimensions of participation is 'engaging the performative and transformative possibilities of storytelling' (Cameron, 2012, p.583), but may equally be counterproductive: 'there is always the risk that the story of an "other" preserves rather than disrupts the status quo' (Pratt, 2009, p.6). We concur with Pratt when she expressed her view on a participatory work collecting testimonies from the Filipino population in Vancouver: 'we hope that the narratives we present produce contradictory and ambivalent emotions - emotions that provoke analysis and critique, rather than replace it' (Pratt, 2009, p.7).

In addition with participatory mapping constructed with migrants, collaborations between the public, artists, geographers, activists using map-making as a critical and creative practice are increasing (Counter Cartographies Collective, Dalton, Mason-Deese, 2012). These indisciplinary mapping practices reactivate links between geography, map-making and art performance, while, at the same time, introducing a social and critical dimension.

By conceiving mapping as practice and performance (Del Casino, Hanna, 2006 ; Crampton, 2009), is it possible to move beyond some of the limitations of the participatory methods?

We will lay particular stress on the multiplication of indisciplinary ${ }^{8}, \operatorname{artivistic}^{9}$ performances

8

As Cattelin and Loty explain 'Indisciplinarity means taking investigations beyond disciplinary boundaries to overcome their ossifying effects. [...] Indisciplinarity directly confronts the paradox of disciplines, which are at once necessary and harmful. [...] "Indisciplinarity" could, with "serendipity", become the essential concept underlying the dynamics of research, just as "interdisciplinarity" became in its 
between art, science and activism, which suggest critical ways of visualizing migration and borders.

\section{[B] Performing the border, mapping performances of border crossings}

The notion of performance is polysemic: it refers to the notion of action, to the act of doing and implementing. 'Performance' as used in social sciences involves studying ways of doing, practices and experiences. In artistic terms, performance means, amongst the physical involvement of bodies or objects in a given place and time, but it also denotes the experience of the artists and the audience who take part in that performance. Rather than involving the 'participation' of the audience, the opposition between artist and audience is overcome by considering the actions of both as part of a common experience. For Phelan (1993), what is important in performance art is the joint presence of the artist and the audience; it is an art based on situations and relationships. When the question of participation becomes that of performance, it is the conception of the subject participating in that experience which changes.

Participatory methodologies aim to associate subjects, often in a subordinate situation, with the production of knowledge; it is as 'subordinate subjects', with the risk of being objectified and naturalized in that category, that they are invited to participate. In performance, the notion of the subject is critical. Since the 1970s, feminist movements have produced performances with the central aim of questioning the idea of the subject, in particular the 'gendered subject/object'. As Begoc, Boulouch and Zabuyan explain: 'Performance is one of the artistic forms which has continually been part of the practice of female artists, and has allowed them to state radically and freely the relationship that they have with the female body by dissociating it from its historical representation, which relegated it to the role of object [...]. By their performances, they subvert predictions and aesthetic formalizations so as to remove the female body from of its compartmentalization in art history and in the stifling idealization of the model and the muse' (Begoc, Boulouch, Zabuyan, 2011, p.17). This critical reformulation of the subject in performance, is particularly interesting in the perspective of a possible reformulation of the category of 'migrant'.

The development of process-oriented mapping practices can also help to deconstruct maps as operators of fixity and territoriality at the expense of practices of mobility. For de Certeau (1990), cartographic representations and everyday mobile practices are in opposition to one another. On the subject of route maps, De Certeau explains that 'surveys of routes miss what was: the act itself of passing by. The operation of walking, wandering, [...] that, the activity of passers-by, is transformed into points that draw a totalizing and reversible line on the map' (de Certeau, 1990, p. 147). In The Practice of Everyday Life, de Certeau critiques the map and its totalizing discourses that impose a disciplinary, 'technocratic' and 'functionalist' ideology on places. He proposes, instead, a 'return to practice', distinguishing the 'itinerary', which lies beyond the visible and readable, from the map.

As a response to de Certeau's critique, researchers, artists, activists, suggest to use mapping as a practice and a performance. Del Casino and Hanna show that: 'maps and mappings are both representations and practices (read: performances) simultaneously. Neither is fully inscribed with meaning as representations nor fully acted out as practices. [...] Maps are [...] not simply representations of particular contexts, places, and times. They are mobile subjects, infused with meaning through contested, complex, intertextual, and interrelated sets of socio-spatial practices.' (Del Casino, Hanna, 2006, p.36-37). Del Casino and Hanna define the idea of 'map spaces' as designating precisely the association of representation, practice and performance which any cartographic document or action implies. One map can give rise to a multiplicity of interpretations and uses.

Border maps cannot therefore be reduced to the surveillance, control and strengthening of

time' (Cattelin, Loty, 2013, p.32). Art/science critical projects in particular can be described as indisciplinary, as they go beyond and question disciplinary boundaries.

$9 \quad$ For a history and an analysis of the neologism 'artivism', see S. Lemoine and S. Ouardi (2010) Artivisme - Art militant et activisme depuis les années 60 (Paris: Editions Alternatives). 
the state's fixist territorial conception. By way of illustrating mapping performances as moments of resistance at borders, we can quote the reappropriation of geospatial technologies by activist organizations along the US-Mexico border. Walsh (2013) studied in particular 'how technologies traditionally aligned with state security and surveillance have been reappropriated in the service of transnational solidarity, recognition and hospitality', studying 'two of the more creative interventions: the placement of water and first aid in the desert, and creation of the Transborder Immigrant Tool (TBIT)' (Walsh, 2013, p.969).

Some mapping practices call into question the national, fixist conception of borders, also by associating bodies in movement with the mapping of mobile borders in situ. Green Line (2007) is a performance by Francis Alÿs in which he walks in Jerusalem along on the border between Palestine and Israel while carrying a leaking can of green paint. As he walks along, the green paint slowly dribbles out of a small hole in the can, leaving behind a wavering line on the ground behind him. On his journey, he crosses through various neighborhoods and streets, inevitably passing through the many security checkpoints that divide the city. A videographer follows Alÿs on his walk, documenting his travel and the green line that is drawn behind him the entire way' ${ }^{10}$. The green line is traced in situ by the moving body of the artist. This performance challenges the fixity of border limits, with reference to the Demarcation Line of 1949 , and their instability and relativity in relation to the mobility of the artist's body, and to that of the inhabitants of the border.

The work of Pedro Lasch is another performance in 'border art' (Amilhat-Szary, 2012), linking questions of mapping, border crossings and migration: 'Pedro Lasch in his work Latino/a America (2003/2006) used a map of the Americas which he gave to Latino/a "wanderers" crossing the border in order to "become attentive to different modes of wandering, of travel, of migration and immigration, with their attendant detentions and deportations" (De Acosta, 2007, p.70)' (Crampton, 2009, p.481). The spectators of these maps are invited to reflect on the embodiement of borders by migrants.

Within video cartography, the artist Bouchra Khalili documents mapping actions performed by those crossing borders in his work Mapping Journey Project (2008-2011). Khalili asked migrants to recount their journeys by drawing their routes on a conventional world map. The migrants' hands are filmed drawing in close-up, while their voices are heard on the sound track telling the story of their journeys. These maps are collections of experiences; perceptions and memories are called up as the shaky lines are drawn on the map. The journey is not laid out clearly once and for all, the mapping makes no claim to showing the route travelled as a finished and clearly defined object. The instability of this video cartography 'based on words and gestures' (Renard, 2011, p.72), stands in contrast to the static border lines drawn on a conventional map, and puts the migrants in the role of 'authors' of their jounreys.

Finally, within the video category, the performances of Ursula Biemann are also very suggestive of political and artistic border practices, and a critical reflection on the experience of borders. The perspective that Biemann adopts criticizes certain classic conventions of the documentary and of maps by refusing to use the authoritative voice-over or the cartographer's view point from overhead. About her work on cross border migrations in the Sahara (Sahara Chronicle, 2006-2009), Biemann explains: 'Sahara Chronicle has no intention to construct a homogenous, overarching, contemporary narrative of a phenomenon that has long roots in colonial Africa and is extremely diverse and fragile in its present social organization and human experience. No authorial voice or any other narrative device is used to tie them together, the meaning is produced by the viewer who has to extract it from the interstices between the videos, i.e. from the connecting lines between the nodes where migratory intensity is bundled, which is the stretch most invisible to the eye. Dispersing the viewpoint acknowledges at the same time the multiple and cooperative process of knowledge produced on the way.' (Biemann, $2009^{11}$ ).

The mapping peformances of Älys, Lasch, Khalili and Biemann share the aim of questioning and transforming ways of visualizing borders by subjecting border lines drawn on a map to the

10 http://www.bordermachines.net/green2.html, date accessed 8 June 2014.

11 http://www.geobodies.org/art-and-videos/sahara-chronicle, date accessed 8 June 2014. 
movements made by physical bodies in space. These performances allow us to read and see the spatiotemporal scope of borders on the basis of the movements of the individuals who -try to- cross them. Mapping mobile borders thus involves showing and putting into practice the mobile and relative space-time of these borders from the point of view of performers and authors on the move, whether they be artists, artivists, activists, researchers or migrants.

The art-science project which we deal with in the next section is part of this critical field of mapping as performance. This project was carried out by researchers in geography, artists and people who had crossed international borders, most of them asylum seekers at the time. This indisciplinary experience explores the possiblity of co-producing creative and critical ways of visualizing mobile borders on maps. It is also a way of considering mapping as a relational practice, useful for the development of the original relationship between researchers, artists and migrants.

\section{[A] CROSSING MAPS : AN EXPERIMENTAL ART-SCIENCE PROJECT OF MAPPING MOBILE BORDERS WITH REFUGEES}

Over a two-month period, in May and June 2013, two researchers, three contemporary artists, twelve refugees, a photographer and a research engineer met together twice a week at the premises of the Association of Asylum Seekers in Grenoble ${ }^{12}$. These workshops were intended to create encounters around mapping practices and to produce alternative narratives on contemporary mobile borders.

In fact this project ${ }^{13}$ arose out of my meeting with two contemporary artists, Marie Moreau and Lauriane Houbey, who together organized mapping workshops in the city of Grenoble. Their exhibition entitled Géographies intérieures ${ }^{14}$ was made up of maps of Grenoble, Europe and the world, of referential and imaginary spaces, co-produced by artists and people that had met in these social organizations. The idea of a co-production of artistic and artivistic maps with people who were often caught in very unstable social and geographic situations, was something to be continued in the framework of a research project on the creative visualization of mobile borders.

With the help of the Association for Asylum Seekers and Coralie Guillemin, the research engineer for the project, I contacted a number of migrants, asking them to participate in mapping workshops. The twelve people who accepted the invitation spoke dozens of different languages, had lived in and travelled through numerous countries, and had been or still were Sudanese, Eritrean, Armenian, Congolese, Guinean, Algerian, Azeri and Afghan. At the time of our meetings, some were asylum seekers or refugees, and others were under the threat of deportation. Thus many had not at that stage obtained refugee statuts or a residence permit. Some of the participants had no permanent home, living mainly in squats, and were regularly moved on, only to set up home again in another part of the city. With no right of residence and nowhere to live, the participants were

12 The premises of the Association for Asylum Seekers (ADA) in the Maison des Associations were used for the workshops. ADA, financed mainly by state subsidies, is one of two associations in Grenoble which help asylum seekers with their administrative procedures. Some of main functions carried out by ADA consist in drawing up and translating life stories, appeals to the CNDA (French court reviewing appeals on refugee status), legal aid, supporting asylum seekers at meetings with the authorities, financing the journey to the CNDA in Paris.

13 Six people ran the workshops: Sarah Mekdjian and Anne-Laure Amilhat-Szary, researchers in geography at the University of Grenoble and at the PACTE laboratory, members of the European research project EUBorderscapes; Marie Moreau, Lauriane Houbey and Fabien Fischer artists and members of the EXCES association; Mabeye Deme, photographer, and Coralie Guillemin, an ADA volunteer who was engaged as a research engineer over the period of the project. The project was funded by the European research project EUBorderscapes, coordinated by Anne-Laure Amilhat-Szary on behalf of the University of Grenoble (http://www.euborderscapes.eu/, date accessed 8 June 2014).

14 The exhibition Géographies intérieures [Interior Geographies] was shown during the winter of 2011-2012 in Grenoble, see : http://www.journee-art-contemporain.com/wpcontent/uploads/2012/09/Dossier_presentation_Laa.pdf, date accessed 8 June 2014. 
themselves clear evidence of how the border extended into their daily lives in France.

In order to portray this mobile border that reached as far as Grenoble, we worked together with four distinct mapping techniques that were suggested by the researchers and the artists: - Sarah Mekdjian and Anne-Laure Amilhat-Szary, researchers in geography at the University of Grenoble, worked with the participants on putting together a shared key for the maps, which each of them used later when drawing their migration map. This shared key was built up after numerous discussions around the choice of key words that were characteristic of their journeys and border crossings. The words were then assigned symbols by the group with the help of stickers of different sizes, colours and shapes.

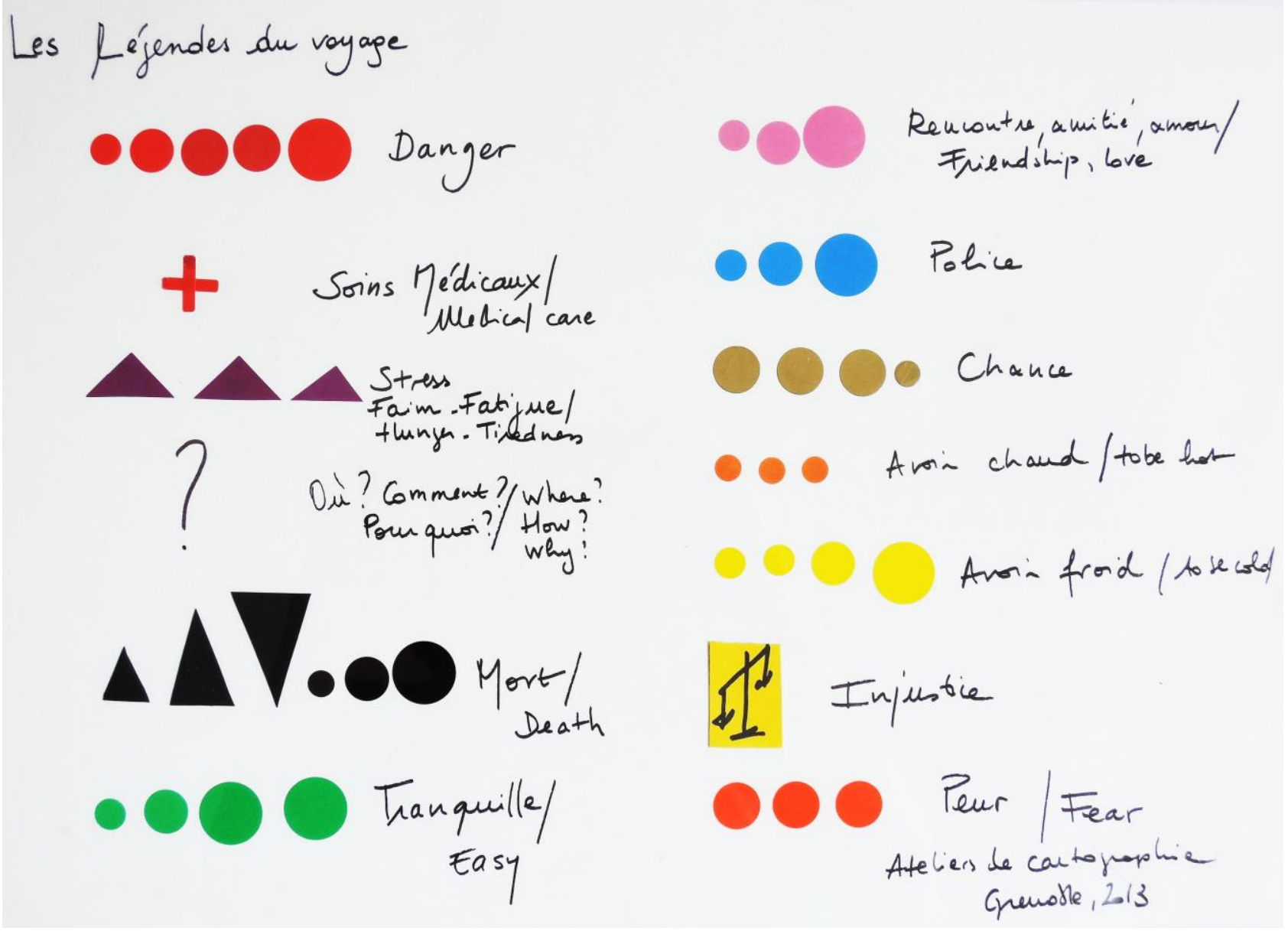

FIGURE 1 - Les légendes du voyage, shared key to the individual migration maps drawn by the participants of the workshops, Grenoble, 2013, CMabeye Deme. 


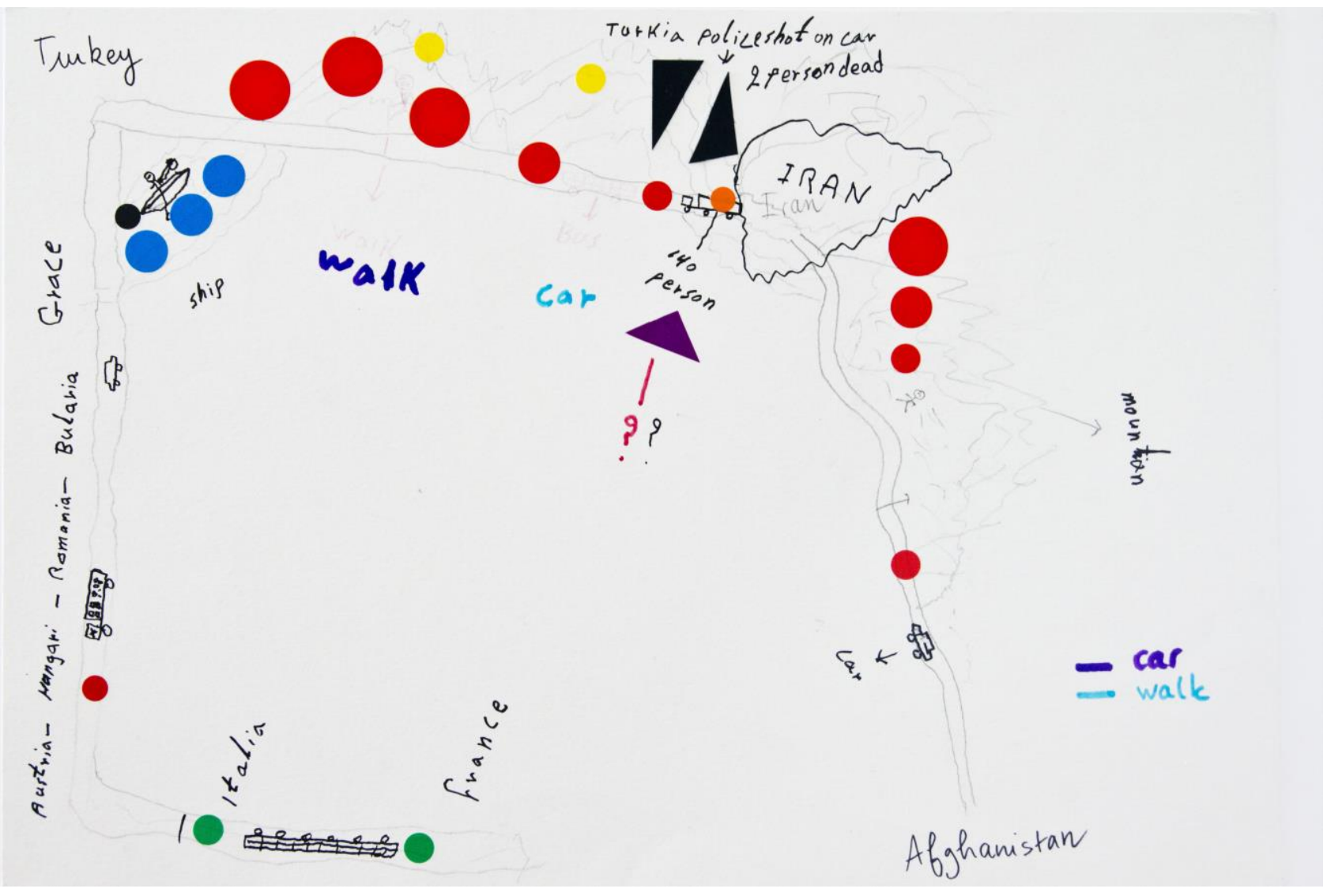

FIGURE 2 - From Afghanistan to France, H. S., Grenoble, 2013, (Mabeye Deme.

-Marie Moreau, visual artist, asked each of the participants to draw his or her journey on large pieces of white cloth which she then partly embroidered; 


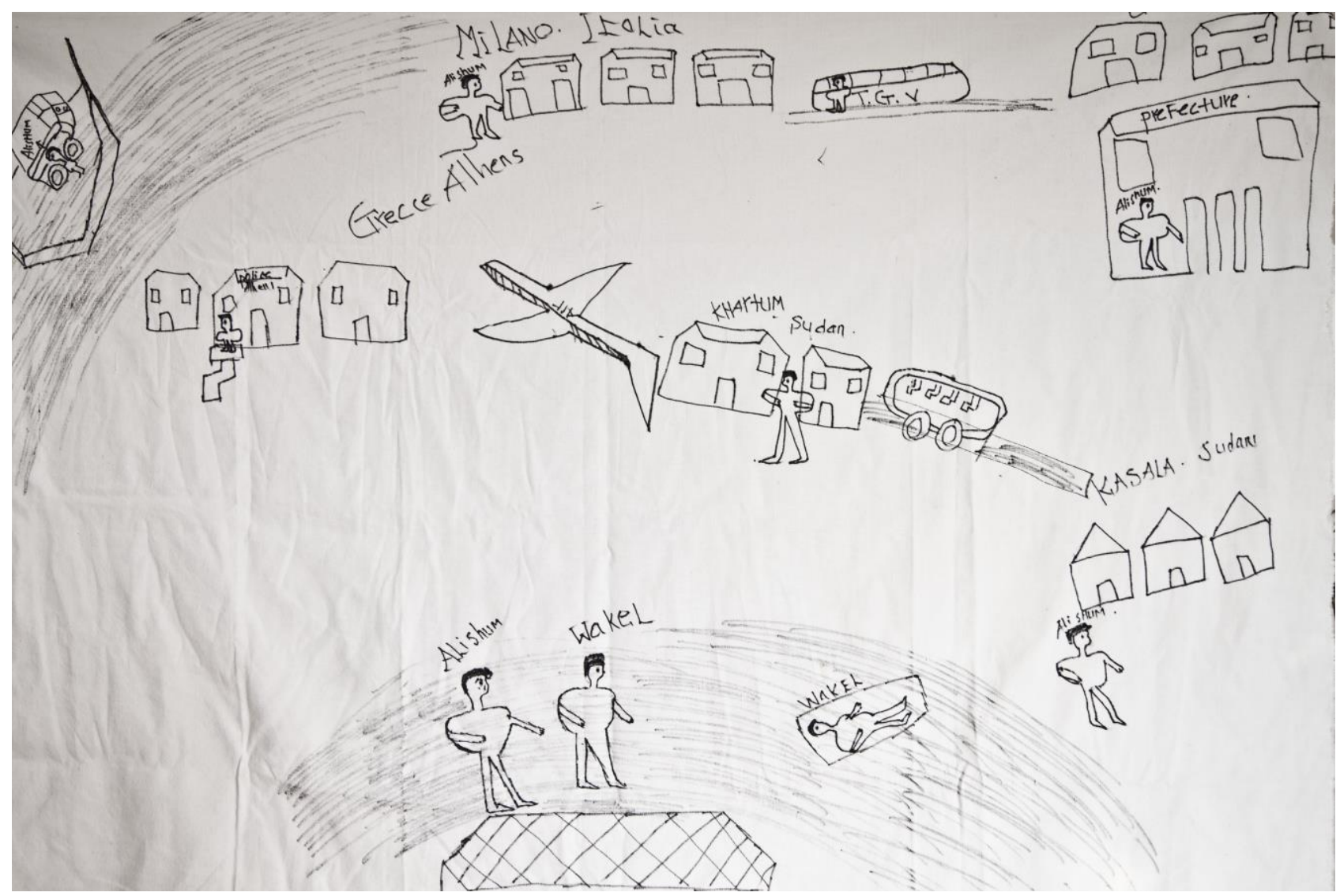

FIGURE 3 - Alishum's journey, A., Grenoble, 2013, CMabeye Deme.

-Lauriane Houbey, visual artist and choreographer, worked with the travellers to make sound maps of the memories of their journeys. Her work was partly based on commentaries on the maps drawn with Sarah Mekdjian, Anne-Laure Amilhat-Szary and Marie Moreau ;

-finally, Fabien Fischer, visual and sound artist, recorded other sound maps relating to the experience of the unstable space-time of daily life in Grenoble.

Out of over fifty maps that were created, the word 'border' [frontière] only appeared on seven, whereas the geo-political lines of the borders between states were absent from the majority of maps. Amongst the words in the shared map key (Figure 1), the term 'border' did not figure, while 'police', 'danger', 'luck' and 'injustice' were rapidly suggested and retained by the participants. It was thus the functions of the borders rather than their existence as objects which were highlighted.

A similar observation can be made about the sound maps recorded with the participants. S., for example, described crossing the border between Turkey and Greece without ever mentioning the word 'border' or an equivalent term. S. talked about a forest in the shape of a 'circle', where dogs were tracking her. The dogs began to bark very loudly and seemed 'to be like death itself', she said.

Everything seemed to operate as though the view of linear borders on conventional maps had partly been short-circuited by vocabulary and images relative to the experiences 'on the way' by the participants at ground level (Figure 2 and Figure 3). During the workshops, participants described the mobile frontiers as a series of events (meeting the 'police', being 'lucky', 'danger', 'death'), sensations and emotions ('being hot', 'being cold', 'being hungry', 'stress, tiredness', 'feeling frightened') and conversations which essentially revolved around 'justice / injustice'. The maps they produced do not show the complete narration of stories, nor conventional mapping from a fixed high point, but numerous alternative stories interwoven and built up from several points of view and projections.

From a methodological point of view, we tried not to reproduce the bias of the ethnographic life-story method, which is too similar to official interviews with migrants. The normative 
interviews carried out by officials ${ }^{15}$ are based on the notions of the 'true' vs. 'lying refugee' : 'the interpretation of the refugee's story in terme sof conformity and deviance relies on expert (institutional) knowledge and on expert experience that must appear to be founded on an objectification of truth and falsehood and that therefore assumes, from the outset, that such obkjectification is possible' (Rousseau, Foxen, 2006, p.506). Thus, while officialdom demands 'verifiable' and 'true' life stories in order to allow - or not - the right to asylum or residence, the maps produced during the workshops were not subject to requirement for 'truth' or 'reality'. They are neither true nor false, neither fictional nor imaginary. They involve visual, textual and verbal means of communication which depend on the relationships built up during the workshop. The maps are neither 'faithful' nor 'unfaithful'. They allow for the expression of memories, stories, feelings, political claims and conversations. The sound maps also differ from the interview method mainly because of the questions asked. Lauriane Houbey and Fabien Fischer spoke with the participants about the sounds and sound ambiances of their journeys; they also asked them to comment on the other maps they had drawn. The memory of sound ambiances together with the physical maps worked together in a process of 'map elicitation' which meant that classic questions about life stories were avoided.

Over the course of two months, the maps that were produced changed. Relationships between individuals and within the group evolved, as did the intentions, the degree of commitment and the expressive methods used by each individual. The maps were a framework within which collective and individual interactions evolved, so that they were a third party in the relationships build up during the workshops. The information expressed by the participants about their journeys and their experience of mobile borders was related to this evolving context of relationships. Marie Moreau explains to what extent mapping can effectively be a situational, relational practice, and thus unstable: 'Outlining a journey, sketching a map, isn't registering land or fixing relationships or trying to capture a shadowy identity. Maps are not for observation. They are for unburdening oneself and a fertile ground for language, gestures, memoirs. [...] The maps create ruptures. New stories emerge in these spaces. Sometimes, from one conversation to the next, two completely different maps are created by the same hand. The map-makers, who use the maps to "represent" (or represent themselves) use them for different reasons. The map represents and reconfigures a relationship to space in a given moment. It is a relative relationship that evolves. This is why the maps are exhibited and circulated.' (Houbey, Moreau, 2012). The exhibition of the maps entitled Crossing Maps has been shown three times to date in different contexts ${ }^{16}$, each time in the presence of the researchers, artists and some participants. The various places and contexts, such as a museum and social and cultural centers, in which the exhibition was presented, allowed the participants to play new roles of 'authors', performing, negociating, and transforming at the same time their roles of 'migrants', 'cartographers' and 'authors'.

This mapping experience raises many methodological and ethical questions as to the conditions on which the migrants, researchers and artists took part, on the alternative narrative methods used, and on the scientific, aesthetic and political uses of the maps produced. Without claiming to have an answer to the limits that a participatory (Elwood, 2007) and experimental method inevitably impose, we consider this project to be a practical demonstration of a critical political dialogue on mobile borders, carried out with those who have experienced them and are still experiencing them on a daily basis. This work also aimed to prepare the ground for an

15 Officers and judges working at the OFPRA (Office Français de Protection des Réfugiés et Apatrides; French Office for the Protection of Refugees and Stateless People) and CNDA Cour Nationale du Droit $d^{\prime}$ Asile; French Court reviewing appeals on refugee status and the asylum right) in France.

16 The exhibition Crossing Maps/Cartographies traverses was shown at Espace Convivi'âge, Grenoble, for the International Day of Refugees, 20 June 2013; at the international art-science exhibition Antiatlas of borders, Tapestry Museum, Aix-en-Provence, France, $1^{\text {st }}$ October-3 November 2013, http://www.antiatlas.net/blog/2013/09/20/crossing-maps-cartographies-traverses/ ; and at the Migrant'Sècne Festival in Grenoble, national festival of the CIMADE (a national non-governmental organisation working with migrants, asylum seekers and refugees in France), 15 November- ${ }^{\text {st }}$ December 2013. 
indisciplinary dialogue between art and science. The joint work between researchers, artists and migrants allowed us to experience cartography in concrete terms as an alternative practice and performance, linked to political issues. We were able to verify in practice what Anne Volvey explains about maps: 'a map [...] is not a finished form, preserved in relation to the world as an inventory or a copy [...], it is a plastic mediator with the world, and in the progressive construction of a world of meaning in and with artistic action: it has a performative, shaping power, it relates less to territory than to giving it new meaning and significant transformation in and with artistic action' (Volvey, 2008, p.15).

\section{[A] CONCLUSION}

In opposition to the conception of a static, linear border-object, we put forward a mobile, situational and relational border, based on the practices and experiences of those crossing them. By considering borders from the point of view of those who experience them or try to cross them, it seems possible to destabilise the idealised picture of fixed, territorial borders. Over and above the externalization of contemporary borders and the deterritorialization process in geosurveillance techniques, it is important to include the situated, relational point of view of the migrants if we are to understand the ways in which borders work. This situational and relational conception of borders calls into question their conventional modes of cartographic representation.

While border mapping has long been dominated by a territorial, state overview, it may be used as an alternative critical tool of the narrative of contemporary borderities. As Quirós and Imhoff (2014) explain, 'while cartography as a discipline has been closely involved in narrating modernity, rationality and positivism, as well as the history of colonialism and national narratives, it has now become the vehicle preferred by artists for the invention of counter-practices and countercartography' (Quirós, Imhoff, 2014, p.6).

Indisciplinary work on maps with artists involves questions on the critical potential of cartography as practice and performance. Beyond the map itself, mapping techniques, the possible practical uses of maps, and cartographic performances as moments of collective and inter-personal relations, become important. The shared scientific and artistic experience of the mapping workshops held in Grenoble in May and June 2013 created relationships between migrants, researchers and artists, as well as between all those taking part in the workshops and the wider public. The visual and sound maps that were produced were shown in various public exhibitions. The maps became the starting point for discussions, questions and claims shared and discussed by the participants, the public, the researchers and the artists. These relational maps also helped in documenting various ways in which mobile borders operate: externalized, deterritorialized, omnipresent in the life of migrants who have been given neither asylum nor a residence permit.

While the maps did not change the daily life of those who took part in the workshops (many are still in a very uncertain position as regards officialdom), they nevertheless did help to question the category and role of 'migrants', to denaturalize conventional ways of representing borders and to encourage a wider witnessing public to think critically about state policies on border surveillance. Writing about activist counter-cartographic work on border crossing between Mexico and the United Sates, Walsh explains: 'in expressive terms their actions disrupt entrenched narratives and may assist in altering the symbolic terrain of the immigration debate and constructing repertories of collective recognition and obligation that advocate for rights and movement and membership' (Walsh, 2013: 979-980). We hope that our work can contribute to this effort, by highlighting the potentiel critical and practical of cartographic techniques in the field of border and migration studies.

\section{References}

A.-L. Amilhat-Szary (2012) 'Walls and Border Art: the Politics of Art Display', Journal of Borderlands Studies, 27, 2, 213-228.

L. Amoore, S. Marmura, M. B. Salter (2008) 'Smart Borders and Mobilities: Spaces, Zones, Enclosures', Surveillance and Society, 5, 2, 96-101 . 
G. Anzaldua (2012) Borderlands - La Frontera: The New Mestiza, $4^{\text {th }}$ edn (San Fransisco: Aunt Lute Books).

C. Audebert and N. Robin (2009) 'L'externalisation des frontières des "Nords" dans les eaux des "Suds"', Cultures et Conflits, 1, 73, 35-51.

J. Begoc, N. Boulouch, E. Zabuyan (2011) La performance: entre archives et pratiques contemporaines (Rennes: Presses universitaires de Rennes).

N. Bernardie-Tahir and C. Schmoll (2012) 'La voix des chercheur(-e)s et la parole du migrant. Ce que les coulisses du terrain maltais nous enseignent', Carnets de Géographes, 4, http://www.carnetsdegeographes.org/PDF/terrain_04_01_Bernardie\%20Tahir_Schmoll.pdf, date accessed 8 June 2014.

J.-M. Besse (2010) 'Cartographies', Carnets du Paysage, 20, 4-9

J. Brachet (2012) 'Géographie du mouvement, géographie en mouvement. La mobilité comme dimension du terrain dans l'étude des migrations', Annales de Géographie, 687-688, 543-560

J. Brinckerhoff Jackson (1984) Discovering the Vernacular Landscape (New Haven: Yale University Press).

E. Brunet-Jailly (ed.) (2007) Borderlands - Comparing Border Security in North America and Europe, (Ottawa: University of Ottawa Press)

E. Cameron (2012) 'New Geographies of Story and Storytelling', Progress in Human geography, $36,5,573-592$.

M. Casas, B. Cobarrubias, J. Pickles (2011) 'Stretching Borders Beyond Sovereign Territories? Mapping EU and Spain's Border Externalization Policies', Geopolitica(s), 2, 1, 77-90.

C. Chataway (2001) 'Negotiating the Observer-Observed Relationship: Participatory Action Research' in D. L. Tolman and M. Brydon-Miller (eds.) From subjects to subjectivities: a handbook of interpretive and participatory methods (New York : New York University Press).

S. Chavez (2011) 'Navigating the US-Mexico Border: the Crossing Strategies of Undocumented Workers in Tijuana, Mexico', Ethnic and Racial Studies, 34, 8, 1320-1337.

O. Clochard, Réseau MIGREUROP (2012) Atlas des migrants en Europe: Géographie critique des politiques migratoires (Paris: Armand Colin).

Counter Cartographies Collective, C. Dalton, L. Mason-Deese (2012) 'Counter (Mapping) Actions: Mapping as Militant Research', ACME - An International E-Journal for Critical Geographies, 11, 3, 439-466.

J. W. Crampton (2009) 'Cartography: Performative, Participatory, Political', Progress in Human Geography, 33, 6, 840-848.

de Acosta A. (2007) 'Latino/a America: a Geophilosophy for Wanderers' in L. Mogul and A. Bhagat (eds.) An atlas of radical cartography (Los Angeles: Journal of Aesthetics and Protest Press).

M. de Certeau (1991) L'invention du quotidien. Tome 1 : Arts de faire (Paris: Gallimard).

V. J. Del Casino and S. P. Hanna (2006) 'Beyond the "Binaries": a Methodological Intervention for Interrogating Maps as Representational Practices', ACME - An International E-Journal for Critical Geographies, 4, 1, 34-56.

C. E. Dunn (2007) 'Participatory GIS: a People's GIS?', Progress in Human Geography, 31, 616-37.

S. Elwood (2006) 'Negotiating Knowledge Production: the Everyday Inclusions, Exclusions, and Contradictions of Participatory GIS Research ', Professional Geographer, 58, 197-208.

S. Elwood (2007) 'Negotiating Participatory Ethics in the Midst of Institutional Ethics', $A C M E-A n$ International E-Journal for Critical Geographies, 6, 329-338.

X. Ferrer-Gallardo (2008) 'The Spanish-Moroccan Border Complex: Processes of Geopolitical, Functional and Symbolic Rebordering', Political Geography, 27, 301-321.

F. Fistetti (2009) Théorie du multiculturalisme. Un parcours entre philosophie et sciences sociales (Paris: La Découverte).

Gibson-Graham J. K. (2002) 'Beyond Global vs. Local : Economic Politics Outside the Binary Frame' in A. Herod and M. Wright (eds.) Geographies of power : Placing scale (Malden, MA: Blackwell).

Hackitectura Collective (2004) 'Critical Cartography of the Strait of Gibraltar' 
http://hackitectura.net/blog/en/2004/cartografia-del-estrecho/, date accessed 8 June 2014.

J. B. Harley (2001) The New Nature of Maps : Essays in the History of Cartography (Baltimore and London: Johns Hopkins University).

L. Houbey and M. Moreau (2012) 'Géographies Intérieures', http://www.journee-artcontemporain.com/wp-content/uploads/2012/09/Dossier_presentation_Laa.pdf, date accessed 8 June 2014.

S. Lemoine and S. Ouardi (2010) Artivisme. Art militant et activisme depuis les années 60 (Paris: Editions Alternatives).

G. E. Marcus (1995) 'Ethnography in/of the World System: the Emergence of Multi-Sited Ethnography', Annual Review of Anthropology, 24, 95-117.

C. Nash (2000) 'Performativity in Practice: Some Recent Work in Cultural Geography', Progress in Human Geography, 24, 653-664.

N. Parker, N.Vaughan-Williams et al. (2009) 'Lines in the Sand? Towards an Agenda for Critical Border Studies', Geopolitics, 14, 3, 582-587.

A. Paasi (2009) 'The Resurgence of the "Region" and "Regional Identity": Theoretical Perspectives and Empirical Observations on Regional Dynamics in Europe', Review of International Studies, 35, 121-146.

C. Perkins and C. Rumford (2013) 'The Politics of (Un)fixity and the Vernacularization of Borders', Global Society, 27, 3, 267-282 .

P. Phelan (1993) Unmarked. The Politics of Performance (London, New York : Routledge).

O. Pliez (2011) Les cités du désert: des villes sahariennes aux saharatowns (Marseille-Toulouse: IRD, PUM).

G. Popescu (2011) Bordering and Ordering the Twenty-First Century: Understanding Borders (Lanham, Maryland : Rowman \& Littlefield Publishers).

G. Pratt (2009) 'Circulating Sadness: Witnessing Filipina Mothers' Stories of Family Separation', Gender, Place \& Culture: A Journal of Feminist Geography, 16, 1, 3-22.

K. Quirós and A. Imhoff (2014) Géo-esthétique (Paris: Editions B42).

I. Renard et al. (2011) La collection d'art contemporain (Paris: Cité nationale de l'histoire de l'immigration-Montag Editions).

D. Retaillé, O. Walther, O. Pissoat (2012) 'Espace, temps, mobilité : cartographier le mouvement et appréhender l'espace mobile pour comprendre l'actualité saharienne', Working Paper, http://halshs.archives-ouvertes.fr/halshs-00767076, date accessed 8 June 2014.

M. Rösler and T. Wendl (eds.) (1999) Frontiers and Borderlands: Anthropological Perspectives (Frankfurt: Peter Lang).

C. Rousseau and P. Foxen (2006) 'Le mythe du réfugié menteur: un mensonge indispensable?/The Social Usefulness of the Lying Refugee', L'Evolution Psychiatrique, 71, 506-520.

Spivak G. C. (1988) 'Can the Subaltern Speak?' in C. Nelson and L. Grossberg (eds.) Marxism and the Interpretation of Culture (London: MacMillan).

P. E. Steinberg (2009) 'Sovereignty, Territory, and the Mapping of Mobility: A View from the Outside', Annals of the Association of American Geographers, 99, 3, 467-495.

C. Sutherland and Y. Cheng (2009) 'Participatory-Action Research with (Im)migrant Women in Two Small Canadian Cities: Using Photovoice in Kingston and Peterborough, Ontario', Journal of Immigrant and Refugee Studies, 7, 290-307.

A. Tarrius (2002) La mondialisation par le bas. Les nouveaux nomades de l'économie souterraine (Paris: Balland).

G. A. Tiberghien (2004) 'Hodologique', Les Carnets du paysage, 11, 6-33.

H. Van Houtum, O. Kramsch, W. Ziefhofer (eds.) (2004) B/ordering Space (London: Ashgate Publishing Limited).

A. Volvey (2008) 'Land arts. Les fabriques spatiales de l'art contemporain', Travaux de l'Institut de Géographie de Reims, 129-130, 3-25 .

J. Walsh (2013) 'Remapping the Border: Geospatial Technologies and Border Activism', Environment and Planning D : Society and Space, 31, 969-987.

D. Wood (1992) The Power of Maps (New York: Guilford Press). 
